3. Brown P., Levinson S. Politeness: Some Universals in Language Usage. Cambridge : Cambridge University Press, 1987. 345 p.

4. Joyce James A Portrait of the Artist as a Young Man. London : Penguin Popular Classics, 1996. 288 p.

5. Wierzbicka A. Understanding cultures through their key words: English, Russian, Polish, German, and Japanese. New York, Oxford : Oxford University Press, 1997. 328 p.

6. Wierzbicka A. Cross-cultural Pragmatics: The Semantics of Human interaction. Berlin/NY : Walter de Gruyter, 2003. 502 p.

7. Woolf V. To the Lighthouse. London : Penguin Popular Classics, 1996. $306 \mathrm{p}$.

DOI https://doi.org/10.30525/978-9934-26-039-1-47

\title{
ТАКТИКИ РЕАЛІЗАЦІЇ ПРЕВЕНТИВНОЇ \\ СТРАТЕГІЇ ВИБОРУ ПАРТНЕРА (НА МАТЕРІАЛІ НІМЕЦЬКОМОВНОГО ВІРТУАЛЬНОГО ДИСКУРСУ)
}

\author{
Пасик Л. А. \\ кандидат філологічних наук, \\ доиент кафедри німеиької філології
}

Волинського національного університету імені Лесі Украӥнки

Рись Л. Ф.

кандидат філологічних наук, доцент, доиент кафедри німецької філології

Волинського національного університету імені Лесі Украӥнки м. Луиьк, Украӥна

Терміни «стратегія» і «тактика» ще й зараз не мають однозначного трактування з точки зору лінгвістів. Дехто вважає «стратегію» ширшим поняттям, як «тактика», а інші їх цілком ототожнюють.

Мета наукової розвідки полягає у 3'ясуванні тактик реалізації превентивної стратегії вибору партнера в оголошеннях про знайомство та в анкетах на сайтах знайомств. Для досягнення поставленої мети необхідно виконати наступні завдання: 1) розглянути сутність превентивної стратегії самопрезентації; 2) виявити тактики реалізації цієї стратегії та проаналізувати мовні засоби їх вираження. 
Дослідженню комунікативних стратегій і тактик приурочено низку праць провідних науковців $[1 ; 2 ; 3 ; 4 ; 5 ; 7]$. На думку О. О. Селіванової, комунікативна стратегія - це складник евристичної інтенційної програми планування дискурсу, його проведення й керування ним із метою досягнення кооперативного результату, ефективності інформаційного обміну та впливу [3, с. 206]. О. С Іссерс вважає, що «стратегія - це когнітивний план спілкування, через який відбувається контроль оптимального рішення комунікативних завдань мовця за умов недостатньої кількості інформації про дії комунікативного партнера» [1, с. 14]. Стосовно поняття «мовна тактика» вчена зауважує: «Мовну тактику варто трактувати як одну чи кілька дій, що сприяють реалізації стратегіiі» [1, с. 16]. Т. ван Дейк зауважує, що стратегія передбачає загальну організацію послідовності дій та охоплює цілі взаємодії. Стратегія пов'язана 3 вибором, який дає змогу досягти таких цілей [5, с. 375-404]. Вибір партнера для створення сім'ї - одне 3 найважливіших рішень у житті людини, і кожен застосовує свої стратегії i тактики для отримання найкращого результату. Однією 3 таких стратегій є превентивна, яка слугує запобіганню небажаних наслідків і втілюється експліцитно та імпліцитно у таких тактиках:

1. Тактика протиставлення бажаних та небажаних претендентів на партнерство - реалізується вживанням мовних засобів заперечення (nicht, nichts, kein, nicht nur), адверзативних сполучників (trotzdem, aber), адверзативних речень 3 парними сполучниками nicht...sondern, kein...sondern, порівняльних речень 3 запереченням nicht so ...wie, лексичних одиниць з відповідним значенням (з негативною оцінною семантикою):

(1) Brauche keinen Mann zum Kästen schleppen, reparieren u.s.w.(Eule1961) [6].

(2) Außerdem ist er kein Mörder, kein Perverser, kein Trinker, kein Junkie und kein entflohener Häftling [9].

(3) ...ich suche keinen "Oma-Typen», sondern eine Frau, die mit beiden Beinen im Leben steht und sich trotzdem nicht so «alt» fühlt, wie es auf einem Stück Papier steht [6].

2. Тактика спонукання до відповіді за певних обмежувальних умов - адресант закликає потенційних партнерів до відповіді, проте наголошує, що вони повинні відповідати поставленим вимогам, в іншому випадку не варто цього робити:

(1) ich w, sehne mich (suche) nach einer neuen Liebe....wenn du das Selbe suchst, zwischen 24-40 J bist und aus München kommst, dann schreib mir!!! [11, vor 6 Monaten]. 
(2) Wenn du ernste Absichten hast und nicht nur eine Bettgeschichte suchst dann melde dich doch einfach mal bei mir [11, vor 6 Monaten].

(3) Wünsche mir für die zweite Lebenshälfte einen Mann für eine feste Beziehung. Er sollte kein Alkoholiker sein und wenn möglich nicht rauchen. Schön wäre es, wenn er größer als 1.78m, schlank u. zw 45-55Jahre alt u. auch berufstätig ist. Wichtig sind mir gegenseitiges Vertrauen, Ehrlichkeit und Harmonie. Außerdem müsste er meine Katze akzeptieren. Ich freue mich auf seriöse, nicht anzügliche Zuschriften. LG Ilona [11, vor 6 Monaten].

3. Тактика припущення та виправдання - адресант припускає, що $\epsilon$ різні люди, у житті яких могли трапитися не дуже позитивні речі, він не засуджує їх, а намагається виправдати, але пов'язувати своє майбуття 3 такими не хоче:

\section{Möglich oder unmöglich?}

Es ist schwer oder? einen Partner zu finden, der weder trockener Alkoholiker, massiv vergangenheitsgeschädigt, noch nicht wieder beziehungsbereit oder sonst wie existenzgescheitert oder massiv beziehungsgestört ist. Gesucht von normaler Sie, 57, mit bewältigter Vergangenheit und Spaß am Leben, attraktivem Äußeren und dem Wissen was sie möchte und was nicht, nämlich eine ganz normale Partnerschaft mit Höhen und Tiefen und allem was dazu gehört .... Noch eine Info an diejenigen, die sich oben angesprochen fühlen...ich habe nichts gegen jene, jedoch bitte schön nicht für mich als Partner, also bitte erspart mir Eure Kritik! liebe Grüße [11, vor 6 Monaten]. Жінка хоче уникнути контактів 3 особами, яким притаманна схильність до таких явищ, як алкоголізм, сумнівне минуле $\mathrm{i}$ втрата бажання жити взагалі, і вона виправдовується перед ними, що не має нічого проти таких осіб, але у ролі свого партнера їх не хотіла б бачити і висловлює прохання не критикувати ії.

4. Тактика надання шансу - автор передбачає, що той, хто раз оступився у житті, міг втратити віру у краще майбутнє для себе i намагається дати йому шанс:

Ein ehemaliger Häftling oder ein trockener Alkoholiker wäre dagegen schon wieder denkbar. Schließlich hat jeder Mensch eine zweite Chance verdient [10].

5. Тактика прохання-заборони - адресанти просять і одночасно забороняють відповідати тим особам, хто не відповідає їхнім критеріям вибору, для того щоб не марнувати часу і не псувати нервів:

(1) Was ich ablehne, sind Machos, verheiratete, liierte, sowie Selbstdarsteller. Von obszönen Bildern oder Angeboten möchte ich verschont bleiben, das ist nicht mein Niveau [10, vor 6 Monaten]. 
(2) Frauen, die sich auf sämtlichen Flirtportalen bewegen, können sich das Schreiben sparen. Haben sehr hohe Ansprüche, aber selber nichts entgegen zu setzen. Ebenso die Unentschlossenen die denken viellt. kommt doch noch was Besseres [11, vor 6 Monaten].

Фактично усі тактики виконують функцію фільтрації або відсіювання потенційних партнерів, що $є$ основою у теорії фільтрів А. Керкгоффа та К. Дейвіса [8, с. 296]. Звичайно, що у текстах оголошень та анкетах не прослідковується чітко наступність стадій, але очевидним $\epsilon$ той факт, що особа обмежує коло потенційних претендентів, вказуючи певні вимоги, серед яких трапляються вказівка на місце проживання, соціальний статус, вік, вага, освітній рівень, акцентуються цінності, переконання та потреби.

Для реалізації цих тактик уживаються такі засоби: заперечні одиниці (nicht, nichts, kein), модальні слова (vielleicht), негативно оцінна лексика (Mörder, Perverser, Trinker, Junkie, entflohener Häftling), лексичні одиниці та словосполучення з відповідною семантикою (unentschlossen, ernste Absichten haben, Kritik ersparen), адверзативні сполучники (trotzdem, aber), адверзативні речення $з$ парними сполучниками nicht...sondern, weder ... noch, порівняльні речення з запереченням nicht so ...wie, умовні безсполучникові речення чи зі сполучником wenn/falls та корелятом dann+Imperativ, питальні речення (Möglich oder unmöglich?), стилістичні фігури: метафори (Sei kein Frosch), епітети (sehne mich (suche) nach einer neuen Liebe), порівняння (und sich nicht so fühlst, wie es auf einem Stück Papier steht), інколи евфемізм (eine Bettgeschichte). Автори вдаються до розмовного стилю та вживання іншомовної лексики.

\section{Література:}

1. Иссерс О. С. Коммуникативные стратегии и тактики русской речи. Изд. 5-е. М. : Изд-во ЛКИ, 2008. 288 с.

2. Пасик Л. А., Рись Л. Ф. Конвергентна стратегія вибору партнера та тактики іiі реалізації (на матеріалі оголошень з рубрики «знайомства» та анкетних даних із сайтів знайомств). Актуальні питання іноземної філологї : наук. журн. / редкол. : І. П. Біскуб (гол. ред.) та ін. Луцьк : Східноєвроп. нац. ун-т ім. Лесі Українки, 2018. № 8. С. 237-242. URL: http://doi.org/10.5281/zenodo.1288348

3. Селіванова О. О. Основи теорії мовної комунікації. Черкаси : Видво Чабаненко Ю. А., 2011. 350 с.

4. Черкасова И. С. Реализация коммуникативной стратегии самопрезентации личности в русских и немецких объявлениях о знакомстве: автореф. дис. ... канд. филол. наук: 10.02.20 «Сравнительно- 
историческое, типологическое и сопоставительное языкознание»; Волгоград, 2006. 23 с.

5. Dijk van Teun A. Cognitive and conversational strategies in the expression of ethnic prejudice. Interdisciplinary Journal for the Study of Discourse. Vol. 3. Issue 4. Amsterdam : Mouton Publishers, 1983. P. 375-404.

6. FlirtCafe. Das Single Portal für Flirten, Dating und Kontaktanzeigen für Singles. URL: http://www.flirtcafe.de

7. Kalishchuk D. Psycholinguistic Methods of Suggestion Strategies Realization as US Presidents' G. Bush Jr. and B. Obama Conceptual Style Markers. Psycholinguistics, 23(2), 2018. 107-119. URL: https://doi.org/10.5281/zenodo.1199146

8. Kerckhoff Alan C., Davis Keith E. Value consensus and need complementarity in mate selection. American sociological review. Vol. 27. 1962. pp. 295-303. URL: https://doi.org/10.2307/2089791

9. Neu.de. URL: http://www.neu.de/

10. Quoka.de URL: http://www.quoka.de/bekanntschaften/partnerschaften-kontakte/kleinanzeigen.html

11. SüddeutscheZeitung. URL: http://anzeigen-suchen.sueddeutsche.de/

DOI https://doi.org/10.30525/978-9934-26-039-1-48

\title{
СИНТАКСИЧНІ ЗАСОБИ ВЕРБАЛІЗАЦІЇ ОБРАЗУ-СИМВОЛУ ЛАБІРИНТ У СУЧАСНИХ АМЕРИКАНСЬКИХ ФЕНТЕЗІЙНИХ ТЕКСТАХ
}

\author{
Стеценко Д. В. \\ аспірантка \\ Київського наџіонального лінгвістичного університету \\ м. Київ, Украӥна
}

Уже багато століть образ лабіринту привертає увагу письменників завдяки своїм енігматичним особливостям і різноманіттю тлумачень. Лексема лабіринт бере свій початок від давньогрецького слова «labyrinthos», що означає «велика будівля $з$ заплутаними пасажами». Своє трактування слово отримало завдяки складній конструкції, в яку була закута міфічна істота Мінотавр на острові Кріт. Нідерландський лінгвіст Роберт Бекес [4] висуває теорію про походження слова labyrinthos від давнішої до-грецької лексеми laura (вузька вулиця, алея, квартал). Досі достеменно невідома етимологія слова лабіринт, що 